\title{
DESVELANDO A PAIXÃO PELO ENSINO DE PROFESSORES DE INGLÊS EM FORMAÇÃO INICIAL
}

\author{
Unveiling Pre-service English Teachers' Passion For Teaching
}

\author{
Jamylla Barbosa Moreira SILVA \\ Escola Estadual. Dr. Raimundo Alves Torres \\ jamyla.moreira@educacao.mg.gov.br \\ https:orcid.org/0000-0001-9763-4699
Ana Maria Ferreira BARCELOS
Universidade Federal de Viçosa anamfb@ufv.br \\ https:orcid.org/0000-0002-2218-5582
}

RESUMO: A formação de docentes de línguas enfrenta vários desafios, entre eles, a pouca atratividade da carreira. Sendo assim, o desejo de ensinar é uma das principais formas através das quais os professores expressam sua paixão e, por isso, uma emoção essencial à promoção de um ensino efetivo (DAY, 2004; 2009). Na Linguística Aplicada no Brasil, ainda não existem estudos sobre a paixão dos professores de inglês pelo seu ofício. Com isso, este trabalho investigou como se constitui a paixão pelo ensino em um grupo de oito professores de inglês em formação inicial, estagiários em um curso de extensão de uma universidade federal mineira. O referencial teórico se pautou em pesquisas relativas ao estudo das emoções no ensino de línguas (BARCELOS, 2015; ZEMBYLAS, 2005) e à paixão pelo ensino (DAY, 2004; 2009; CARBONNEAU et al., 2008; MART, 2013). Os dados foram coletados através de (1) questionários abertos, (2) entrevistas e (3) narrativas visuais e submetidos à análise de conteúdo. Os resultados revelaram que os participantes sentem paixão pelo ensino, haja vista manifestarem desejo de ensinar, gosto pelo inglês, emoções positivas e cuidado e comprometimento ao se engajarem em sua prática docente em seus contextos de ensino. PALAVRAS-CHAVES: Formação Inicial; Ensino de inglês; Paixão.

\begin{abstract}
Language teaching education faces several challenges, such as, the little attractiveness for the career. Thus, the desire for teaching is one of the main ways through which teachers show their passion and, therefore, an essential emotion for the promotion of an effective teaching (DAY, 2004; 2009). In Applied Linguistics in Brazil, there have been no studies yet about the passion of English teachers
\end{abstract}


for their work. Therefore, this study investigated the construction of the passion for teaching in a group of eight pre-service teachers of English working in an outreach course of English at a federal university in Minas Gerais. The literature review was based on studies related to the study of emotions in language teaching (BARCELOS, 2015; ZEMBYLAS, 2005) and passion for teaching (DAY, 2004; 2009; CARBONNEAU et al., 2008; MART, 2013). Data was collected through (1) open-ended questionnaires, (2) interviews and (3) visual narratives and subjected to content analysis. The results revealed that these participants feel passion for teaching, given that they manifest the desire for teaching, their love for English, positive emotions and caring and commitment in engaging with their practice in their teaching contexts.

KEY WORDS: Pre-service Teaching; English Teaching; Passion.

\section{INTRODUÇÃO}

Um dos desafios da formação de professores de línguas diz respeito à falta de vontade de vários licenciandos em seguir a carreira docente. Diferentes estudos constataram (CORTEZ, 2012; OLIVEIRA, 2012; TARDIF, 2014) que, ao ingressar na licenciatura, poucos desses graduandos evidenciam o desejo e a perspectiva de se tornarem professores de Língua Inglesa (doravante LI). Há algum tempo, outros estudos na mesma direção apontam para a necessidade de uma reflexão maior acerca do processo de formação de línguas nos cursos de Letras (PAIVA, 1997; SOUZA, 2013; FLORES, 2015). Não obstante, segundo Day (2004), a paixão pelo ensino é condição sine qua non para um ensino eficaz. Para ele (Ibidem), a emoção da paixão pelo ofício gera satisfação, motivação, confiança e entusiasmo no docente, além de ser essencial a um ensino efetivo.

Tendo em vista a emoção da paixão como indispensável ao desenvolvimento do trabalho docente efetivo, e por não existirem pesquisas no Brasil na área de Formação de Professores de Línguas que abordem essa temática, este artigo traz um recorte do estudo de Silva (2018) sobre esse tema. Esse estudo investigou e identificou como se constitui a paixão, as identidades profissionais e a relação entre ambas em um grupo de oito professores de inglês em formação inicial. Esses participantes são estagiários em um curso de extensão de LI, pertencente a um projeto de ensino e extensão de uma universidade federal mineira. Neste artigo, entretanto, devido a limitações de espaço e tempo, focamos apenas na emoção da paixão desses professores.

Este trabalho está dividido em cinco seções (incluindo a introdução). Na segunda seção, apresentamos o referencial teórico sobre formação de professores de língua e emoções, com foco na paixão pelo ensino. Na terceira, apresentamos o contexto 
e os procedimentos metodológicos. Por fim, discutimos os resultados e tecemos as considerações finais.

\section{REVISÃO DE LITERATURA}

Nesta seção, discorremos sobre dois conceitos fundamentais para esta pesquisa. $\mathrm{Na}$ primeira parte, conceituamos as emoções e abordamos alguns estudos que investigaram esse conceito na formação inicial de professores de línguas. Na segunda, discutimos e trazemos trabalhos referentes à paixão pelo ensino.

\section{Emoções na formação de professores}

Nos últimos anos, internacionalmente, os estudos sobre emoções têm ocupado maior espaço dentro da Linguística Aplicada (doravante LA) (BARCELOS e COELHO, 2016; BENESCH, 2008; KING, 2018). De forma semelhante, também no Brasil, aumentam as pesquisas sobre essa temática (ARAGÃO, 2008; COELHO, 2011; CANDIDO RIBEIRO, 2012; REZENDE, 2014; RODRIGUES, 2015; BATTISTELLA, 2016; PADULA, 2016; ARCANJO, S., 2019; GODOY, 2020). Esse crescimento deriva do reconhecimento de que o ensino não envolve somente o conhecimento cognitivo dos professores, mas também de suas emoções em interação com o contexto em que estão inseridos.

As emoções podem ser despertadas e direcionadas por pessoas, valores e ideais. De acordo com Zembylas (2005, p.468-469), o processo de ensino "é mais do que um corpo do conhecimento ou uma lista concreta de práticas e habilidades: é uma maneira de ser e sentir historicamente em relação aos outros". Ainda segundo esse autor, o trabalho dos professores envolve o conteúdo, a aprendizagem de seus alunos, a interação com eles, a metodologia de ensino e a forma como eles se sentem diante do desenvolvimento de suas aulas. Esse autor afirma ainda que os estudos sobre emoções de professores enfatizam como elas estão relacionadas à vida deles e ao papel que desempenham no processo de ensino/aprendizagem. Assim, a forma com que os professores compreendem, vivenciam, atuam e falam sobre elas está relacionada à construção de suas identidades.

Existem várias definições para o complexo conceito de emoções. Na Psicologia, por exemplo, Izard (1991) as define como um sentimento que motiva, organiza e conduz à percepção, ao pensamento e à ação do indivíduo. Na LA, esse termo é conceituado por So (2005, p.44) como "o resultado psicológico das interações dinâmicas entre diferentes camadas de sistemas internos e externos fisiológicos, cognitivos, comportamentais e 
sociais". Na Biologia do Conhecer", as emoções são vistas como "disposições corporais dinâmicas que modulam ações e relações possíveis, num dado momento de um fluir histórico" (ARAGÃO, 2008, p. 296). Zembylas (2002a, 2002b, 2003, 2004) compreendeas como sendo conceitos sociais, culturais e políticos. Elas nascem na interação social, não sendo apenas psicológicas e restritas ao indivíduo, como antes eram compreendidas. Para ele, a importância das emoções está ligada ao fato de elas serem a chave para efetuar mudanças. Por sua vez, ao levar em conta que o ensino integra o lado profissional e o pessoal, a mente e a emoção, Day (2004) considera essencial que, a fim de promover um ensino efetivo, os professores sintam e mantenham sua paixão por ensinar.

Por ser um conceito complexo, com variadas definições em meio à diferentes perspectivas, é importante nos aprofundarmos sobre as características das emoções. Para tanto, tomemos as palavras de Solomon (2004), para quem elas são:

(a) Comportamentais: incluem expressões faciais e verbais, relatos e planos elaborados para a ação; (b) Físicas: incluem alterações hormonais, neurológicas e neuromusculares; (c) Fenomenológicas: incluem sensações físicas, formas de ver e descrever os objetos conforme as emoções de uma determinada pessoa, bem como "metaemoções"; (d) Cognitivas: referem-se às avaliações, percepções, pensamentos e reflexões sobre as próprias emoções; (e) Sociais: relacionam-se às interações pessoais e culturais ${ }^{2}$.

Fundamentadas na citação acima, compreendemos o termo em discussão não somente como biológico ou social, mas também cognitivo, comportamental e fenomenológico. De outras partes, investigações na Educação e na Psicologia Social (BOSMA; KUNNEN, 2001; MESQUITA, 2004; MARKUS, 2004; ZEMBYLAS, 2004) caracterizam as emoções tal qual: ativas, interativas e processuais; hierárquicas, discursivas e culturalmente construídas. Como vemos, esses estudos apresentam uma visão significativamente mais ampla e à altura e contrariam a caracterização desse conceito complexo como algo passivo. Já os trabalhos brasileiros sobre emoções na formação inicial e em serviço de professores que vêm sendo feitos no Brasil (ARAGÃO, 2008; CANDIDO RIBEIRO, 2012; ARCANJO, 2019; ARCANJO, 2019; GODOY, 2020;

\footnotetext{
${ }^{1}$ A Biologia do Conhecer, de Humberto Maturana (2008), é "um mecanismo explicativo dos sistemas vivos, caracterizados como sistemas dinâmicos operacionalmente fechados a instruções do meio, tratados como seres em constante transformação no viver e em permanente acoplamento estrutural com o meio. Com efeito, todo o viver é um conhecer, e todo o conhecer é um viver [...] A Biologia do Conhecer nos permite abordar sistemicamente os processos de ensino/aprendizagem" (ARAGÃO, 2005, p.104).

${ }^{2}$ Grifos organizacionais nossos (a), (b) etc.
}

Revista X, v. 16, n. 2, p. 381-408, 2021. 
CARVALHO, 2020) revelam que as emoções são engendradas no ambiente onde se ensinam e se aprendem línguas e nas relações construídas naquele contexto.

Aragão (2008) pesquisou as emoções de sete futuros professores de inglês da Faculdade de Letras da Universidade Federal de Minas Gerais e a importância da prática reflexiva em sua formação. Através da história de ensino/aprendizagem dos participantes, bem como de suas narrativas visuais, o estudo apontado revelou a relevância das emoções no desenvolvimento de habilidades orais na reflexão e na responsabilidade por suas trajetórias profissionais. Adiante, Candido Ribeiro (2012) investigou os estados afetivos nas práticas de professoras em formação inicial a fim de entender como a afetividade das participantes era construída em sala de aula. Os resultados sugeriram que as professoras vivenciaram estados afetivos diferentes gerados, em geral, por interações com alunos e pelo contexto de trabalho.

Mais recentemente, ao apresentar a relação entre a motivação e emoções de uma professora de LI em formação inicial e as de seus alunos, Arcanjo (2019a) identificou emoções de amor, felicidade, medo/insegurança, insatisfação e tristeza por parte da professora. Nesse âmbito, apesar das dificuldades do trabalho, a emoção do amor foi frequentemente expressa. Por sua vez, Arcanjo (2019b) debruçou-se sobre a relação entre as emoções e a motivação em um grupo de professores de LI em formação inicial e a influência do curso de Letras a esse respeito. Utilizando questionários abertos, narrativas escritas, visuais e entrevistas, os resultados alcançados por essa última pesquisa sugeriram a influência do curso de Letras na motivação dos participantes, haja vista suas intenções de fazer a diferença na vida de outras, ao compartilharem seus conhecimentos. Essas motivações se relacionavam às emoções de satisfação e prazer, enquanto outras incluíram o medo e a insegurança.

\section{Paixão pelo ensino}

Neste artigo, a discussão sobre a emoção da paixão, pauta-se, sobretudo, em “Passion for teaching”(2004). Nessa obra, esse conceito não é empregado no sentido romantizado, porquanto as pessoas podem ter um sentimento intenso e profundo por alguém, mas também por aquilo que gostam de fazer, ter, etc. Desse modo, ao passo que advém de múltiplas situações, essa emoção pode ser definida como "qualquer tipo de sentimento que afeta ou influencia a mente" (Ibidem, p.39).

A paixão é objeto de estudo em diferentes áreas de conhecimento, como a Filosofia, a Psicologia e a Semiótica. Na Educação, essa emoção é vista como um fator fundamental para promover um ensino bem-sucedido. Day (2004, p.35) define paixão como "uma Revista X, v. 16, n. 2, p. 381-408, 2021. 
guia, uma força motivadora que origina da força da emoção. Ser ou estar apaixonado gera energia, determinação, convicção e comprometimento". Carbonneau et al. (2008, p. 978) definem paixão como "uma forte inclinação ou desejo para uma atividade que se gosta e se encontra importante, e em que se investe tempo e energia". Esses autores ainda sugerem que o desejo é uma das formas do professor manter sua paixão pelo ensino.

No exterior, as pesquisas de Ensino e Aprendizagem relacionadas à paixão se concentram na Formação de Professores, nas Culturas Escolares e na Qualidade do Ensino (DAY, 2004; MART, 2013; HARDEN, 2012; LAIDLAW, 1998). Nacionalmente, ainda são raros os trabalhos que se voltam à paixão de docentes pelo ensino de LI (CRUZ, 2013; BORGES, 2009; LAGO, 2009; LIMA, 2016; SILVA, 2018). Nesse sentido, os estudos de Borges e Lago (2009) e o de Cruz (2013) evidenciam que o gosto pela LI é uma forma pela qual o professor demonstra a paixão por ensinar. Essa proposição vai ao encontro da concepção defendida por Day (2004; 2009), na qual afirma que o professor apaixonado tem interesse pelo campo de conhecimento no qual está situado e, por isso, quer sempre fazer o melhor, aprender mais e buscar métodos mais eficientes.

Apesar dos possíveis desafios cotidianamente perpassados em seus contextos profissionais, Day (2009) afirma que todos os professores são capazes de se apaixonar por seus ofícios. Para ele, essa emoção pode ser motivada e construída na prática docente, na interação com os alunos e no trabalho cooperativo e colaborativo com estudantes e colegas de trabalho. Ao elencarem algumas características importantes para o que consideram ser um bom professor, Hargreaves, Shaw e Fink (1997, p.18) indicam que quando ele tem paixão pelo seu trabalho, seus alunos aprendem eficazmente, pois "mudanças pedagógicas falham, quando não envolvem as paixões da sala de aula".

Segundo as proposições sugeridas por Day (2004), professores apaixonados:

(a) Expressam emoções naturais como medo, alegria e raiva; (b) Demonstram entusiasmo, cuidado e comprometimento em seu trabalho; (c) Têm esperança em relação ao seu trabalho e à sua profissão; (d) Conhecem os desafios que enfrentam nos amplos contextos sociais em que ensinam; (e) Sabem do papel que as emoções desempenham na aprendizagem e no ensino da sala de aula; (f) Acreditam que podem fazer a diferença na aprendizagem efetiva de seus alunos; (g) Demonstram ser criativos; (h) Expressam suas crenças em relação ao ensino e ao seu trabalho. ${ }^{3}$

\footnotetext{
${ }^{3}$ Grifos organizacionais nossos (a), (b), etc. 
O autor supracitado (Ibidem, p.43) ainda destaca que os professores só lograrão sucesso em seu trabalho quando forem capazes de alimentar e expressar a sua paixão pelo ensino e pelos alunos. Day (2004) afirma que:

[...] todos que trabalham com criança e jovens, todos os que viram ou ouviram muitos professores que 'amam', de uma forma clara, o seu trabalho e as crianças e jovens a quem ensinam, reconhecerão que a vocação do ensino talvez esteja relacionada acima de tudo com o amor (DAY, 2004, p.43).

Ensinar se relaciona ao amor por envolver confiança, respeito e depender dos relacionamentos próximos existentes na sala de aula, como a relação entre o professor e seus alunos. Na Psicologia Positiva, Barcelos e Coelho (2016) ressaltam que o amor está intrinsicamente relacionado à capacidade de respeitar os outros. Segundo Paulo Freire (1996), a base de todo o processo educativo é o amor, gerado na relação com o outro. Assim, o ensino não está associado apenas ao conhecimento do professor e ao conteúdo pedagógico, mas também requer compromisso intelectual e emocional (DAY, 2004). Diante das conquistas e dos desafios que podem existir desde a formação inicial à estabilidade da carreira, Day (2009) afirma que a paixão do professor está relacionada aos sentimentos, à criação de ambientes que possam proporcionar emoções positivas e ao saber evitar e lidar com aquelas que são negativas no trabalho docente.

\section{METODOLOGIA}

Esta pesquisa foi realizada ${ }^{4}$ com um grupo de oito alunos do curso de Letras Português/Inglês, que estagiam como professores de LI em um Curso de Extensão de Línguas de uma universidade federal de Minas Gerais. Esse é um projeto vinculado ao ensino, à pesquisa e à extensão de tal instituição. Para estagiar nesse projeto, todo primeiro semestre de cada ano, os alunos do curso de Letras podem pleitear uma vaga em um treinamento pedagógico, e, se aprovados, passam a fazer parte da equipe de professores de tal projeto.

\footnotetext{
${ }^{4}$ A investigação da qual provém os dados ora apresentados foi aprovada pelo Comitê de Ética em Pesquisa com Seres Humanos da universidade em que foi desenvolvida, em consonância à Plataforma Brasil. Destarte, todos os respectivos procedimentos metodológicos foram realizados em observância às normas estabelecidas pelo CEP a nível institucional, assegurando-se o consentimento, a preservação da privacidade e da anonimidade dos participantes. Além disso, foram respeitados todos os princípios éticos concernentes à Pesquisa Qualitativa.
} 
Os participantes do estudo em questão realizaram esse treinamento no primeiro semestre de 2016, foram aprovados e começaram a exercer a prática docente no segundo semestre do mesmo ano. A escolha de professores em formação inicial se deu pelo fato de eles terem manifestado o interesse de lecionar já no primeiro semestre do curso de Letras, ao se candidatarem a uma vaga para professores nesse projeto. Os participantes foram identificados como: Clara, Joana, Lúcia, Mariana, Celso, Miguel, Nikolas e Paulo, eles têm entre 19 a 26 anos. Durante a coleta de dados, realizada em 2017, seis deles estavam no $5^{\circ}$ período do curso de Letras e dois no $7^{\circ}$. Cinco deles não haviam tido experiência de ensino com a LI antes do ingresso na graduação, enquanto outros três já haviam tido. Para dois dos oito participantes, Letras se configura como o segundo curso superior: Paulo é formado em Enfermagem e Joana, em Comércio Exterior.

Os dados foram coletados através de uma narrativa escrita, uma visual e de duas entrevistas. Para guiar a narrativa escrita, um roteiro foi enviado aos participantes. Assim, solicitou-se o relato de suas motivações e influências para optar pela licenciatura em Letras, por se tornarem professores de Inglês, bem como as suas emoções e perspectivas relativas à docência. Para cada um dos participantes, foram realizadas duas entrevistas semiestruturadas: 1) a primeira teve por objetivo compreender suas impressões em relação à formação por meio de sua prática docente no curso de extensão; como se constituíam suas paixões pelo ensino e, ademais, solucionar dúvidas acerca dos relatos constantes nas narrativas escritas e/ou nas descrições das narrativas visuais. 2) Já a realização da segunda interação teve como intuito investigar suas emoções em relação ao contexto que lecionavam e como suas paixões pelo ensino contribuíam à construção de suas respectivas identidades docentes.

Segundo Kalaja et al. (2008), diversas ferramentas visuais, como fotografias, objetos materiais e artefatos culturais ou familiares têm sido utilizadas nos estudos relacionados à Formação de Professores para expressar as memórias e as relações dos indivíduos com a linguagem, por meio de histórias de vida. No Brasil, o uso dessas narrativas visuais tem ganhado importância como instrumento de coleta de dados em alguns estudos sobre emoções, motivações e identidades no processo de ensino e aprendizagem de línguas (ARAGÃO, 2008; MOREIRA, 2015; OLIVEIRA, 2016; PALMER, 2018; ARCANJO, 2019; GODOY, 2020). Neste estudo, cada participante foi orientado a fazer um desenho que representasse sua paixão pelo ensino, levando-se em conta suas práticas docentes no curso de LI. Para auxiliar na interpretação dos dados, conforme a metodologia de narrativas visuais desenvolvida por Kalaja et al. (2008), no verso das folhas, os participantes forneceram uma explicação a respeito de suas ilustrações. 
A análise dos dados seguiu procedimentos baseados em autores como Holliday (2002) e Denzin e Lincoln (2006), a saber: (a) Leitura da narrativa escrita e das entrevistas para identificação de unidades significativas; após a verificação, as unidades mais recorrentes foram agrupadas, formando-se as categorias iniciais. (b) Na triangulação dos dados, após um processo constante de revisão, releitura e reagrupamento das categorias iniciais, foram mantidas aquelas mais recorrentes, que apresentaram as características de professor apaixonado por seu ofício, identificadas nos relatos e nas representações visuais dos participantes.

Em relação à análise das narrativas visuais, Pitkänen-Huhta e Pietikäinen (2014) propõem três estratégias para analisá-las: olhar, ver e/ou projetar. Segundo as autoras, a estratégia do olhar se relaciona ao uso de fotografias como uma ferramenta documental à observação; a segunda, ver, refere-se à observação física de algo e à consciência do que se vê; já a terceira, projetar, está associada à colaboração entre os participantes e os pesquisadores para agirem sobre suas reflexões e produzirem algo com base na visualidade. De modo geral, qualquer uma dessas estratégias pode ser uma forma de investigar como a linguagem pode ser expressa literal ou metaforicamente. A análise das narrativas visuais apresentadas nesse estudo foi baseada na segunda estratégia de Pitkänen-Huhta e Pietikäinen (2014): o termo ver está relacionado não somente à percepção de algo físico, utilizando o sentido da visão, mas também se refere aos processos de reflexão, compreensão e interpretação de uma determinada imagem, ou seja, ver o que o participante quer dizer; e observar os aspectos representados: elementos da natureza, sala de aula, metáforas e autorretrato (KALAJA, 2008). Através da descrição dos desenhos, foi possível analisar informações recorrentes com intuito de ilustrar e comparar o que subjaz os relatos dos participantes em outros instrumentos de coleta de dados.

\section{DISCUSSÃO DOS RESULTADOS}

Nesta seção, discutimos as categorias que constituem a paixão pelo ensino desse grupo de professores, sendo elas: a) o desejo de ser professor de LI, b) o gosto pela LI, c) as emoções (positivas) em relação ao ensino e d) o cuidado e o comprometimento.

\section{Desejo de ser professor de LI}

O conhecimento a respeito do desejo de se tornar professor, como e quando ele surgiu, e o que levou esses professores em formação inicial a desejarem exercer essa prática são formas de compreender como se constituem as paixões dos participantes deste Revista X, v. 16, n. 2, p. 381-408, 2021. 
estudo (DAY, 2004; 2009) pelo ensino de LI. Em seus relatos, geralmente, sugerem que o anseio de ensinar, manifestado logo no primeiro semestre do curso de Letras, foi motivado por diferentes momentos de suas vidas, por diferentes fatores, tais quais: a influência de terceiros; o contato com o ensino de inglês, antes ou depois do ingresso na licenciatura em Letras, e a vontade de ser um instrumento de mudança social.

Três alunos, Lúcia, Paulo e Miguel, mencionaram o desejo influenciado por terceiros. Lúcia, por exemplo, afirma que foi motivada pela vocação de sua família, particularmente, a de seus pais, que são professores:

\section{Excerto [1]}

Lúcia: Eu sempre quis lecionar. Sempre carreguei no peito esse desejo de ser professora, porque meus pais são professores, assim como muitos outros membros da minha família (NE, Lúcia, 7/3/2017) ${ }^{5}$

Ela enfatiza a importância da sua família na influência de seu desejo de ser professora. De acordo com Moreira (2017), a decisão por uma profissão não é uma escolha individual, mas pode ser construída por um conjunto de fatores externos que também envolvem as pessoas com as quais nos relacionamos ao longo da vida, assim como Lúcia sente com relação à família.

Além da influência de outras pessoas, os dados evidenciam que o contato com o ensino, antes ou depois de ingressar no curso de Letras, fomentou o desejo de alguns deles de querer seguir na carreira docente. Acerca disso, dois participantes expressam essa vontade. Miguel considera a sua experiência como monitor de inglês em curso de línguas como sua maior motivação para sua projeção na carreira docente:

\section{Excerto [2]}

Miguel: Em tempos de escola sempre imaginei como seria a vida de um professor, e comecei a me interessar e pesquisar mais a fundo. Um dos motivos que me levaram a ser professor de inglês foram as monitorias que fazia antes e durante a Universidade, o que vale como experiência que, aliás, tem sido extremamente auxiliadora na minha formação (NE, Miguel,7/3/2017).

A motivação desse participante para ensinar, apresentada neste excerto, está associada ao seu desejo pela docência (MOREIRA, 2017), nutrido desde a educação

\footnotetext{
${ }^{5}$ Cada excerto está enumerado e identificado da seguinte forma: letras iniciais dos nomes de cada instrumento, a saber: narrativa escrita (NE), narrativa visual (NV), primeira entrevista (E1) e segunda entrevista (E2); sucedido pelo pseudônimo do participante e pela data de coleta do instrumento em questão.
} 
básica. O seu relato evidencia que seu contato com o ensino de inglês, através da atuação em uma monitoria, fomentou sua vontade de querer ser professor. Ao exercer essa função durante a formação inicial, esse anseio foi reafirmado e tal experiência é vista como uma influência importante para o desenvolvimento de sua formação docente, e, consequentemente, à construção de sua identidade como professor de inglês.

No caso de Joana, o curso de extensão de LI onde estagiava, contexto de realização desta pesquisa, foi essencial na construção do seu desejo de lecionar. A participante destaca o treinamento pedagógico realizado nesse curso de línguas como um fator importante em sua formação, conforme revela:

\begin{abstract}
Excerto [3]
Joana: Como gostava muito de aprender outras línguas, principalmente o inglês, em 2010 fiz vestibular e consegui uma bolsa em uma faculdade para cursar comércio exterior. Terminei o curso e percebi que não era o que eu realmente gostaria de fazer no futuro. Então, em 2014 decidi que o curso de Letras seria uma ótima oportunidade para aprender mais sobre as línguas; fiz o vestibular e comecei o curso em 2015. No primeiro momento não tinha muito interesse em dar aulas, mas com o decorrer do curso de Letras queria descobrir se eu era capaz de ensinar outra língua (...) O treinamento pedagógico possibilitou que eu descobrisse em mim um desejo de ensinar. (NE, Joana, 7/3/2017).
\end{abstract}

Neste excerto, Joana confirma que tal curso de treinamento estimulou seu desejo de ensinar. Até então, ela não demonstrava interesse pelo ensino, embora afirme que gostava do inglês, o que a levou a cursar, primeiramente, Comércio Exterior e, posteriormente, Letras. Assim, a decisão pela licenciatura teve como intuito um maior aprendizado sobre línguas.

Diferentemente dos demais participantes, Nicolas afirma que o seu desejo de se tornar professor está associado à sua busca de ser um mediador social e à sua afinidade com línguas:

\footnotetext{
Excerto [4]

Nicolas: Resolvi ser professor para juntar o útil ao agradável. Estava inconformado com o tipo de pessoas que me rodeavam, e precisava fazer algo a respeito. Cheguei à conclusão que não era meu texto no facebook que ia melhorar algo, é a educação. E como sempre tive afinidade com o aprendizado de idiomas, pareceu a escolha certa a se fazer. Usar a sala de aula como um centro de reabilitação para o mundo (NE, Nicolas, 7/3/2017).
}

Neste fragmento, Nicolas justifica a vontade de ensinar para "usar a sala de aula como um centro de reabilitação para o mundo", sugerindo esse ambiente escolar Revista X, v. 16, n. 2, p. 381-408, 2021. 
como um instrumento social. Explicando essa ideia, esclarece que "ser professor não é somente ensinar, mas é ajudar na mudança do mundo" (E1, Nicolas 18/4/2017). Com essa afirmação, podemos inferir a importância de que o professor seja um profissional crítico-reflexivo (LEFFA, 2011) e não somente um transmissor do conteúdo, mas também fomentador de discussões sobre questões afins, por meio da troca de conhecimento com seus alunos (DAY, 2004), conforme narrativa visual:
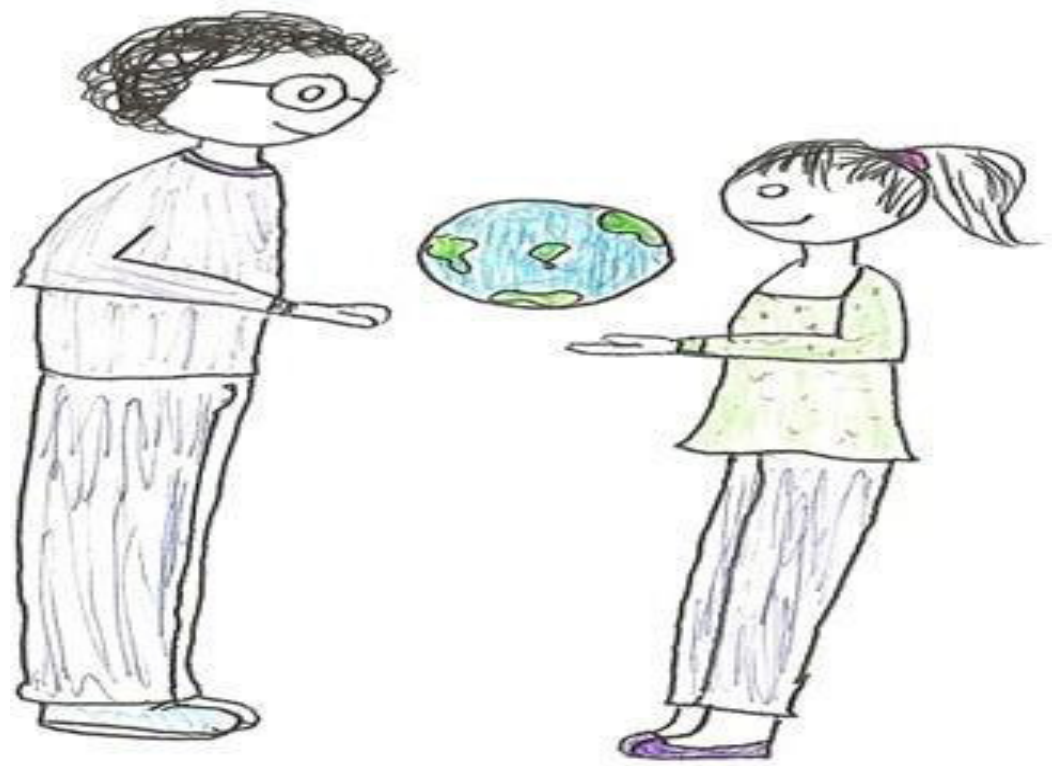

NV 1:

"Ensinar, especialmente, em outra língua, é compartilhar um mundo 'novo' com o outro" (NV, Nicolas, 14/3/2017).

\#PraCegoVer: Desenho colorido. Duas pessoas, uma de frente para a outra, elas estão sorrindo. Lado esquerdo um adulto, cabelos cacheados, usa óculos, blusa cinza de mangas compridas, calça preta e tênis azul claro. Lado direito, uma adolescente, cabelos compridos e amarrados no alto da cabeça, usa blusa verde de manga comprida, calça preta e sapatilha azul marinho. Os dois estão com os braços estendidos à frente do corpo e entre eles o desenho do planeta Terra, oceano azul e continentes verdes.

Nesta narrativa visual, temos a figura de um aluno do lado esquerdo (ele usa óculos, calça comprida e camisa) e de uma aluna do lado direito (ela usa blusa de manga comprida e uma calça comprida). No meio dos dois, encontra-se o desenho do Planeta Terra (em azul e verde), ambos têm uma expressão sorridente no rosto. A descrição da respectiva narrativa também indica que, para Nicolas, pelo uso da expressão "um mundo novo", o ensino de línguas, como o ensino de LI, não se refere somente à transmissão 
de conhecimento linguístico e gramatical aos aprendizes, como é priorizado por muitos professores, principalmente no contexto escolar (MOREIRA, 2015), mas também à cultura daquela língua, no caso o inglês.

\section{Gosto pela LI}

Dentre as características de um professor apaixonado, destaca-se o gosto pelo campo de conhecimento no qual atua, isto é, aquele que assume paixão por sua disciplina (HARDEN e LAIDLAW, 2012). Segundo Mart (2013), o termo paixão é usado pelos alunos em alguns estudos na área da Educação, ao descrever seus melhores professores como aqueles que têm paixão pela matéria que lecionam. Nessa mesma direção, todos os oito participantes desse estudo demonstraram gostar e ter afinidade com a LI.

Mariana demonstra seu gosto pelo inglês e destaca a importância de ensinar o conhecimento pelo qual tem interesse. Essa afirmação pode ser confirmada em sua resposta em uma das entrevistas, ao justificar como se sente em lecionar a LI, no excerto 5:

\section{Excerto [5]}

Pesquisadora: Você menciona também o seu gosto pela língua inglesa. Como você se sente em ensinar esta língua?

Mariana: Eu gosto (...) eu sempre gostei da língua, é muito bom ensinar uma coisa que eu realmente gosto (E1, Mariana, 20/4/2017).

Mariana parece acreditar que é bom ensinar algo que se goste. Segundo Day (2004), para lograr sucesso em sua prática de ensino, os professores devem ser capazes de alimentar e expressar sua paixão pelo seu campo de conhecimento e pelo ensino. Assim, a afinidade que a participante nutre pela LI é essencial à promoção de um ensino efetivo, o que a caracteriza como uma professora apaixonada. Lúcia, por sua vez, afirma se sentir à vontade com o inglês, por isso, o ensino dessa língua se torna um trabalho prazeroso. A ideia em discussão pode ser confirmada em sua primeira entrevista:

\section{Excerto [6]}

Lúcia: Eu me sinto muito à vontade com a língua inglesa $[\ldots] \mathrm{O}$ ensino de línguas para mim é muito engraçado, é divertido; me traz uma calma, uma paz interior, é muito confortável [...] É aquele tipo de trabalho que não me cansa. Me dá prazer (E1, Lúcia, 20/4/2017).

Os professores apaixonados transmitem entusiasmo pelo seu ensino (DAY, 2004; HARDEN e LAIDLAW, 2012), tal como Lúcia sugere no excerto 6, ao afirmar que, para 
ela, ensinar é um trabalho que traz diversão e tranquilidade. Essa ideia é reafirmada em sua narrativa visual, um autorretrato, em que Lúcia representa a calma sentida quando acredita ter ministrado uma boa aula.

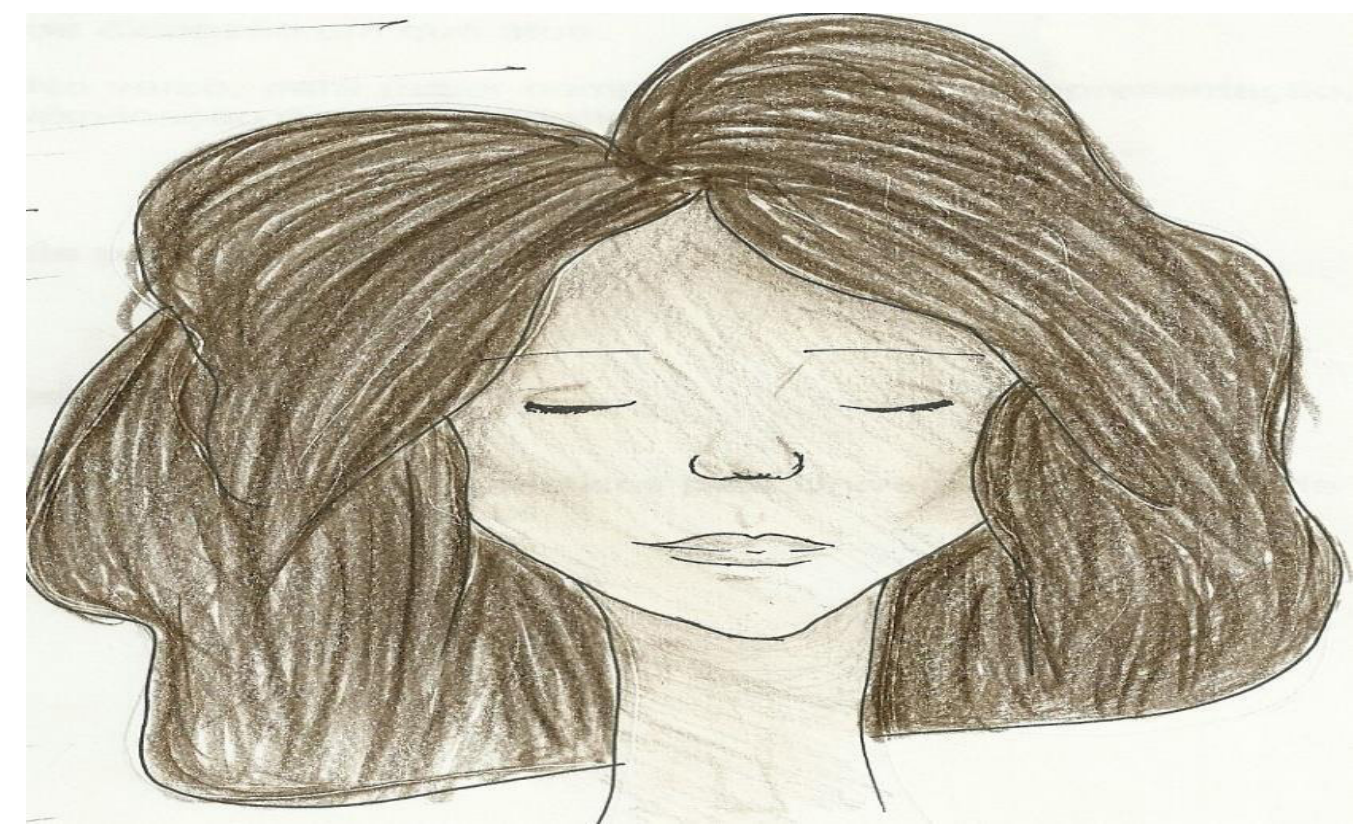

V 2:

"No desenho eu quis representar a calma/leveza que é gerada ao dar uma aula bem-sucedida. Sem contar na tranquilidade e segurança que devemos demonstrar ao ensinar" (NV, Lúcia, 14/3/2017).

\#PraCegoVer: Desenho na cor marrom, vista frontal do rosto de uma mulher. Ela tem pele clara e cabelos lisos, castanhos na altura do ombro. Os olhos estão fechados, nariz e boca finos, seu semblante está calmo, tranquilo.

Em sua narrativa visual, a participante desenha o rosto de uma mulher com cabelos médios castanhos e uma expressão serena (olhos fechados). Através da descrição de sua narrativa visual, Lúcia afirma ainda que, ao ensinar, é necessário o professor demonstrar estar tranquilo e seguro, características sugeridas pelo semblante sereno apresentado no autorretrato em alusão.

\section{Emoções}

Os participantes deste estudo expressaram a vivência de várias emoções positivas, tais quais: felicidade, alegria, satisfação, gratidão e esperança. Afelicidade e a satisfação Revista X, v. 16, n. 2, p. 381-408, 2021. 
foram observadas e evidenciadas como emoções que os levaram a se sentirem cada vez mais motivados pelas atividades realizadas no exercício do trabalho docente, bem como pela profissão em geral. Coincidentemente, segundo Day (2004), a motivação pelo trabalho é uma das principais características do professor apaixonado.

A felicidade foi a emoção mais mencionada pelos participantes. Nicolas, Mariana, Lúcia, Joana, Miguel e Celso a expressam no desenvolvimento de seu trabalho e também em relação ao contexto que ensinam, no caso, o curso de extensão em LI. No que diz respeito às emoções em relação ao contexto de prática, Celso enfatiza sua felicidade, ao destacar sua prática no curso de inglês como uma oportunidade de conhecer mais sobre a profissão docente.

Excerto [7]

Celso: Eu me sinto feliz quando eu consigo colocar na prática aquilo que eu aprendi. Eu me sinto alegre de trabalhar no curso de extensão de inglês. De poder trabalhar com os meus alunos e fazer ali todas as atividades que eu tenho vontade de fazer, que eu vejo que tem como dar certo e testar isso. Eu me sinto muito feliz (E2, Celso, 27/10/2017).

Celso relaciona a sua felicidade ao fato de, no cerne do projeto em que leciona, poder atrelar a teoria à prática. Nesse sentido, essa experiência parece motivá-lo a escolher atividades a partir das quais espera resultados positivos. Isso lhe desperta a alegria de estar inserido nesse projeto. Para Day (2004), os contextos escolares desempenham uma influência-chave na capacidade de os professores manterem sua paixão, assim como percebemos no excerto 7. A felicidade de Celso está relacionada à expectativa de êxito, à motivação e à satisfação em lecionar, além do ambiente onde exerce sua prática. De modo análogo, Paulo também relata sentir satisfação ao ensinar:

Excerto [8]

Paulo: As minhas emoções são muito boas porque a primeira coisa, como eu disse no início, é que eu me sinto realizado, valorizado. Eu vejo que meu trabalho é reconhecido, a minha sensação é o reconhecimento do meu trabalho. (...) A minha emoção principal é o reconhecimento, eu me sinto satisfeito de estar no CELIN (E2, Paulo,6/11/2017).

Neste excerto, Paulo afirma ter boas emoções em relação à sua prática docente, haja vista o reconhecimento de seu trabalho, que faz com que ele se sinta satisfeito em atuar como professor do projeto de ensino em questão. Da mesma forma, em sua NV, pautada nos resultados positivos alcançados ao final de uma aula que superou suas expectativas, Clara expressa sua satisfação por seu trabalho: 


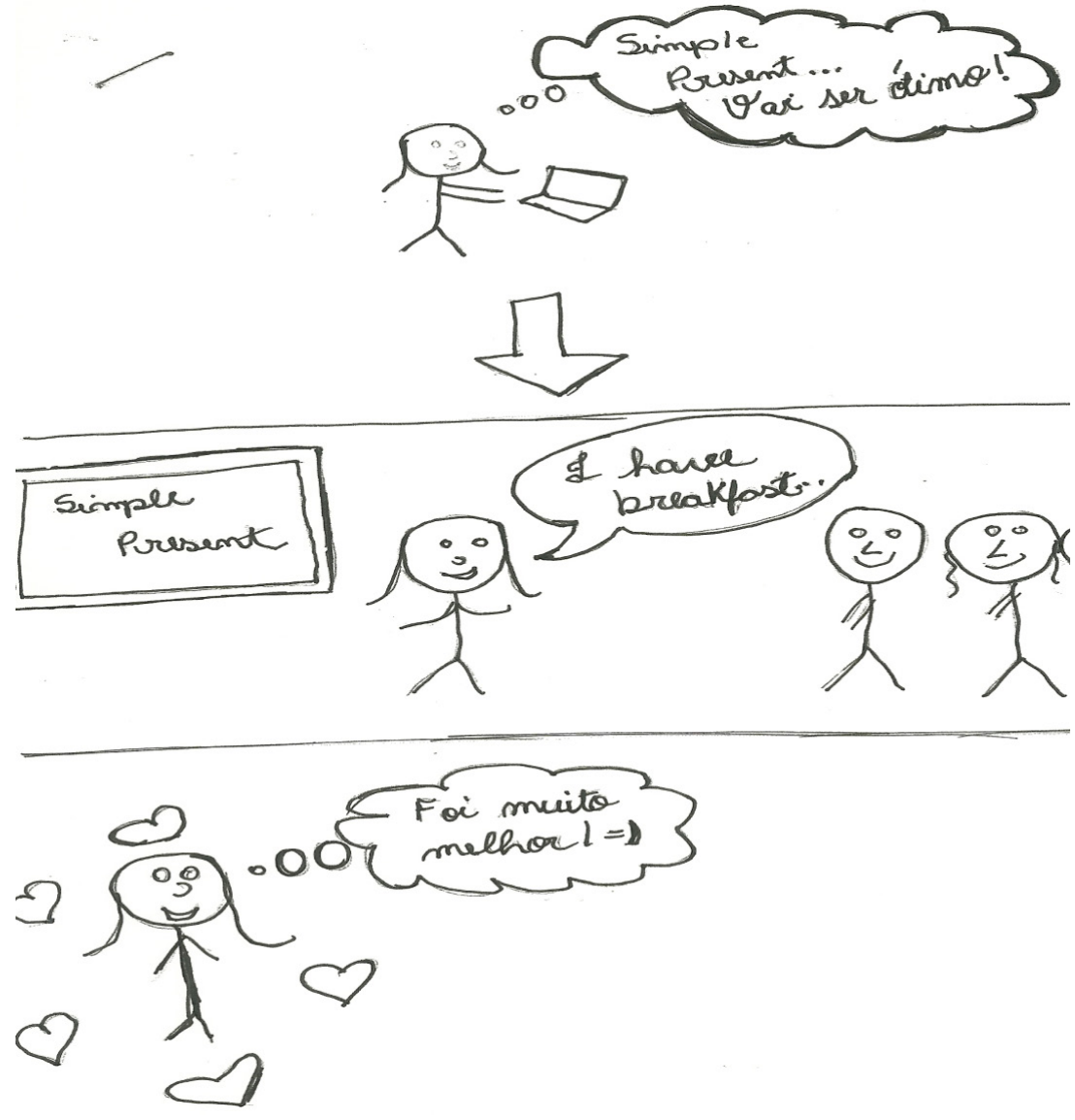

NV 3:

"Quando penso como vai ser minhas aulas, sempre penso como vai ser bom e proveitoso, mas sempre quando saio da sala de aula vejo que com a participação dos alunos a aula foi muito melhor do que imaginei. Isso é gratificante". (NV, Clara, 14/3/2017)

\#PraCegoVer: Desenho na cor preta organizado em três partes na vertical. Primeira: uma mulher em frente ao computador, balão de pensamento: Simple Present... vai ser ótimo! Ela está sorridente. Segunda: um quadro onde está escrito Simple Present. Uma mulher ao lado do quadro, balão de fala I have breakfast. Duas crianças sorridentes, um menino e uma menina em frente a mulher. Terceira: a mulher com vários corações em volta, bem alegre, balão de pensamento: Foi muito melhor! =) .

O desenho de Clara tem três partes divididas por linhas horizontais, com figuras feitas em traços. Na primeira, há um aluno com um livro aberto e um balão com os dizeres: "simple present... vai ser ótimo!". Na segunda, temos o que acreditamos ser uma sala de aula - um quadro onde está escrito "Simple present" e uma figura feminina com um balão de fala contendo a frase: "I have breakfast". Além disso, há duas outras figuras que parecem ser os alunos, sorridentes. Na última, temos a imagem da professora rodeada 
por corações e com um balão de fala onde aparecem os dizeres: "Foi muito melhor! =]". Seu desenho ilustra as expectativas em relação ao planejamento para suas aulas e a satisfação gerada pelo resultado positivo que ela acredita obter.

A aula sobre o Simple Present (Presente simples) é utilizada como exemplo em sua NV e sugere que o resultado desse trabalho supera as expectativas da participante. Os termos "Vai ser ótimo" (na primeira situação ilustrada) e "Foi muito melhor" (na última) clarificam uma satisfação interior, caracterizada como "gratificante". A paixão de Clara é demonstrada pela motivação que sente por seu trabalho e através da satisfação gerada nesse processo (DAY, 2009; SILVA, 2018). Na NV, os corações ilustrados ao redor de uma pessoa sugerem que esteja sendo apresentada a própria forma através da qual Clara se autorrepresenta. Tal desenho sugere o amor que ela sente pelo seu ofício. Em outros termos, denota a emoção gerada na relação com o outro (FREIRE, 1996), na realização do trabalho em sala de aula, na interação com os alunos e na satisfação em compartilhar conhecimento a respeito da LI.

\section{Cuidado e Comprometimento}

De acordo com Day (2009), professores apaixonados expressam cuidado e comprometimento, características-chave para promover um ensino efetivo. A fim de promover uma aprendizagem significativa a seus alunos de acordo com as suas necessidades de aprendizagem, todos os participantes demonstram ter preocupação e compromisso com seu trabalho.

Ao se declarar uma professora de inglês apaixonada, Joana acredita ter uma interação efetiva com seus alunos, o que contribui para o ensino e/ou aprendizagem bemsucedidos de LI. A ideia em referência é ilustrada na seguinte narrativa visual:

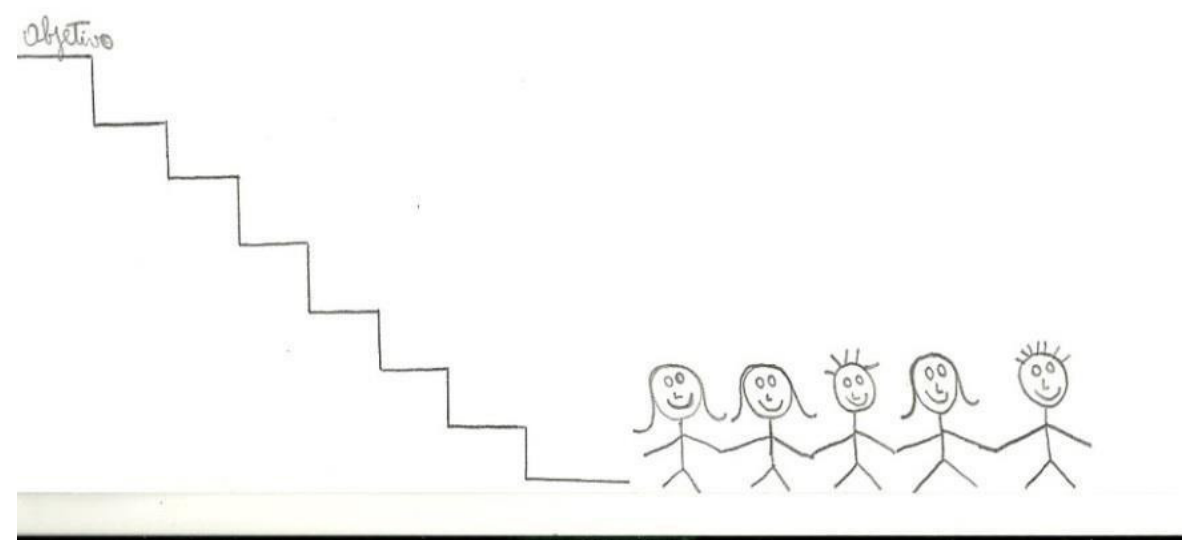


NV 4:

"Sou apaixonada em ensinar inglês porque durante as aulas eu e meus alunos construímos juntos o conhecimento e nos unimos para seguir em direção ao nosso objetivo, que podem ser diferentes, mas acabam se unindo durante as aulas" (NV, Joana 14/3/2017).

\#PraCegoVer: Desenho na cor preta. Lado direito superior a palavra Objetivo, abaixo traços em forma de escada com sete degraus. Na base, lado direito cinco pessoas de mãos dadas. Todas sorriem. Três pessoas têm cabelos lisos pelo ombro e duas têm cabelos curtos arrepiados.

Nesta narrativa visual, temos uma escada alta, ao lado esquerdo. Logo ao pé da escada, temos a figura dos alunos e da professora (desenhados com traços) com mãos dadas. Cada degrau da escada representa uma etapa para alcançar o objetivo, no caso, um ensino e aprendizagem efetivos. Na descrição da NV apresentada por ela, infere-se que Joana se iguala aos seus alunos e que é na interação com eles que o conhecimento de aula é construído. Para Day (2004), a natureza de um bom ensino pressupõe o cuidado para com aqueles que ensinamos. Joana demonstra, para preparar suas aulas, também levar em conta o nível de conhecimento de seus aprendizes em relação à LI, conforme se verifica no excerto a seguir:

\section{Excerto [9]}

Pesquisador: O que você leva em conta para planejar as suas aulas?

Joana: Eu levo em conta as dificuldades que meus alunos têm, porque a maioria entra no nível do curso sem saber nada de inglês. E o nível não tem muitas coisas introdutórias. Eu penso o que eles têm de bagagem e o que não têm. Eu também levo exercícios que se baseiam na realidade deles, coisas que realmente eles vão usar e que vão dar sentido a eles, e não só completar os espaços. (E1, Joana, 20/4/2017).

Quando Joana relata que pensa "o que eles têm de bagagem e o que não têm”, leva em consideração o conhecimento de seus alunos sobre um determinado conteúdo de LI ao preparar as suas aulas. Em outras palavras, ao buscar proporcionar aprendizagem significativa aos seus alunos, a concedente sugere que o bom ensino envolve o cuidado e o comprometimento do professor em fazer o melhor que pode, em todas as circunstâncias, para o bem de seus alunos (DAY, 2004). Em sua resposta, ela demonstra ainda a preocupação de conhecer as dificuldades de aprendizagem dos alunos e de trazer exercícios que possam levá-los a um pensamento crítico: "não só completar os espaços", como ela mesma diz. Assim, mostra a crença que o ensino de inglês não deve ser apenas baseado no ensino de gramática, com exercícios tradicionais de completar, e, sim, em 
atividades que permitam os alunos praticarem a língua e terem pensamentos críticos (OLIVEIRA, 2012; MOREIRA, 2015).

Da mesma forma, Miguel, no excerto 11, relata que não propõe atividades baseadas apenas em teorias gramaticais, mas também na reflexão crítica para auxiliar seus alunos a terem um pensamento crítico no processo de ensino-aprendizagem:

\section{Excerto [11]}

Miguel: Então, eu vejo que professor para mim não é só aquele que ensina, que dá a aula; é aquele que ensina você ter um pensamento crítico. Isso é o que eu tento fazer nas aulas, não só ensino a gramática, mas eu faço os alunos refletirem o que eles querem para vida deles, o que aquele problema está trazendo, como podemos discutir. Então como professor, eu tenho muito orgulho desse título, porque para mim professor mesmo é aquele que tem o objetivo de formar alunos críticos, e não só dar uma mera aula (E1, Miguel,19/4/2017)

Neste excerto, Miguel revela sua concepção de ensino baseada na relação teoria e prática, ou seja, para ele é importante não somente mostrar como o inglês deve ser usado, mas ter oportunidades de desenvolver essa prática em sala. Miguel acredita que o "professor mesmo" é aquele que cumpre o seu real papel na sala de aula: formar alunos críticos. Podemos afirmar que essa visão está de acordo com a concepção de ensino de Leffa (2011), que discute o ensino não como treinamento, mas como um processo para se formar cidadãos reflexivos. Para desenvolver esse tipo de aula, Miguel relata que considera o conhecimento prévio dos alunos sobre a LI e elenca cuidados no desenvolvimento das atividades em suas aulas, como o tempo de cada uma:

\section{Exceto [12]}

Miguel: Eu levo em conta, principalmente, o que os alunos já sabem e o que eu posso avançar mais, porque não adianta eu apresentar uma coisa totalmente nova para eles, se eles não têm uma base antes. (...) Eu levo em conta também o tempo da aula, quanto que cada atividade vai durar, e o tipo de atividade que vou dar, seja música, vídeo, algum jogo, algumas coisas assim. Analiso se vai ser realmente produtiva, se eles vão aprender alguma coisa, se eles vão ter algum ganho disso; e quais são as implicações disso para eles no futuro. (E1, Miguel,19/4/2017).

Miguel afirma que, ao proporcionar uma atividade, tem a preocupação de atender e contribuir com as necessidades de aprendizagem dos alunos, julgando se ela vai ser produtiva ou não, e planejadas de acordo com os interesses deles. O desejo de ajudálos no processo de aprendizagem é uma das características-chave de um bom professor 
(HAAVIO, 1969 apud DAY, 2004). Através do excerto 12, podemos dizer que Miguel é um professor que se compromete apaixonadamente com o seu trabalho, pois procura métodos mais eficazes de interagir com seus alunos (DAY, 2009), como planejar aulas com músicas, vídeos e jogos atrativos que acredita serem próximos da realidade de seus estudantes. Ademais, ele considera importante a interação dos alunos na sala de aula para esse processo se tornar efetivo, o que pode ser verificado na narrativa visual a seguir:

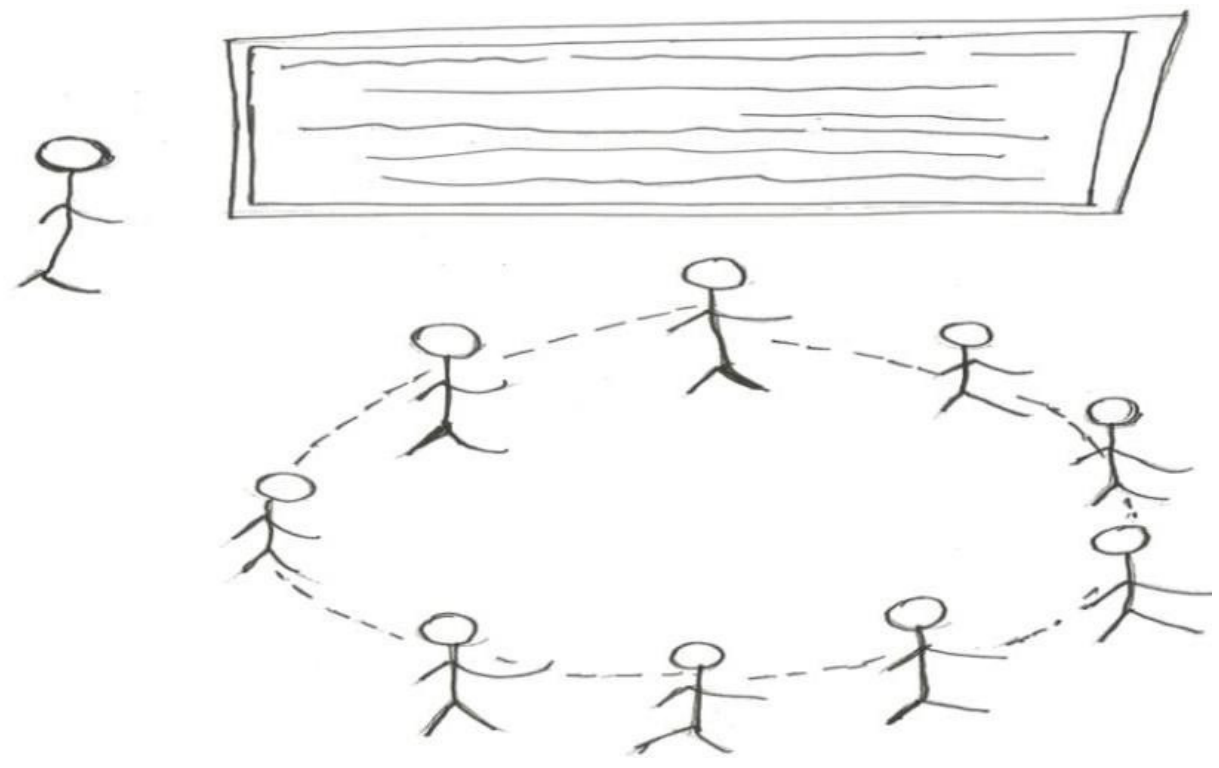

NV 5:

"Eu acredito em interação. Quando os estudantes se interagem o aprendizado pode ser melhor. Eu acho que isto é possível quando os estudantes trabalham juntos e fazem o seu melhor, com respeito mútuo" (NV, Miguel - 14/3/2017).

\#PraCegoVer: Desenho na cor preta, acima e centralizado um grande quadro negro cheio de traços ilegíveis, ao lado esquerdo uma pessoa em pé. Abaixo, em frente ao quadro, nove pessoas em pé formam um círculo e entre elas linhas tracejadas.

Nesta narrativa visual, temos desenho de alunos com traços, mas não há expressões em seus rostos. Há uma figura ao lado de um quadro, que tem várias linhas (provavelmente um quadro todo escrito) e, em frente a esse quadro, 9 alunos, em pé, em círculo. $\mathrm{Na}$ justificativa da representação, Miguel enfatiza que a aprendizagem de seus alunos pode ser bem-sucedida através da interação entre eles, em um trabalho conjunto e colaborativo, 
no qual todos se respeitam. Ensinar envolve confiança e respeito entre todas as partes, isto é, docente e aprendiz (DAY, 2004).

O comprometimento e a dedicação de Joana e Miguel e dos outros participantes deste estudo, seja buscando metodologias diferentes e mais eficazes para seus alunos, conhecendo suas preferências em relação ao inglês, proporcionando a interação com seus alunos e/ou entre eles e querendo formar alunos críticos, são atributos que os caracterizam como professores apaixonados.

\section{CONSIDERAÇÕES FINAIS}

Neste artigo, procuramos identificar como se constitui a paixão de um grupo de professores de inglês em formação inicial. Essa discussão se baseou em uma abordagem teórica interdisciplinar que dialoga com estudos na LA e na Educação, tendo os estudos de Day $(2004 ; 2009)$ como norteadores para a análise realizada. Dessa forma, à guisa de conclusão, fazemos quatro considerações.

Em primeiro lugar, os resultados evidenciaram que os oitos participantes deste estudo demonstraram ter paixão pelo ensino de inglês, que se revela mais especificamente na prática de ensino no referido curso de LI. Conforme afirmado anteriormente, a emoção da paixão envolve um desejo por aquilo que se gosta e se gasta tempo e energia. De acordo com essa definição, os resultados indicaram que todos os participantes mostraram ser professores apaixonados, por gostarem da LI, por se sentirem motivados a ensinar essa língua e/ou por expressarem emoções como felicidade, alegria, satisfação, amor e entusiasmo em relação ao ensino. Além disso, dessas emoções positivas, a paixão pelo ensino desses participantes é constituída, em geral, pelo desejo de ser professor, pelo gosto pela LI e pelo comprometimento e cuidado na interação com seus alunos. O fazer diferente desses participantes está associado ao desejo de proporcionar uma aprendizagem efetiva para seus alunos. A maioria deles relatou buscar uma boa interação com seus alunos e entre eles e afirma ter cuidado e comprometimento em planejar suas aulas, no desenvolvimento de sua prática, além de utilizarem metodologias de acordo com o interesse e necessidades de aprendizagem de seus alunos. Isso demonstra cuidado e comprometimento, o que, segundo Day (2004), são essenciais para identificar a paixão de professores pelo ensino.

Em segundo lugar, o contexto do curso de LI no qual os participantes estagiam os motiva a querer promover um ensino de qualidade e a seguir nessa profissão, além de manter e alimentar a sua paixão por ensinar inglês. Eles destacam que as orientações metodológicas e pedagógicas, além do desenvolvimento linguístico e comunicativo de Revista X, v. 16, n. 2, p. 381-408, 2021. 
inglês, proporcionados durante essa prática, contribuíram à construção de sua paixão por essa profissão. Isso sugere a importância de vivência da prática ainda durante a graduação e de aliar a prática à teoria. Estamos cientes que poderemos ser questionadas se essa paixão se mostrou saliente nesses professores, devido ao tipo de contexto em que atuaram: um projeto de extensão e ensino onde desfrutam de liberdade para planejar suas aulas e orientação e supervisão pedagógicas efetivas. Podem nos questionar se todos os professores em formação têm garantia de um contexto assim, ou mesmo, se após formados, terão condições de atuarem em um contexto que os apoie. A julgar pela realidade brasileira de sucateamento da educação e de muitas condições insuficientes ao ensino e aprendizagem de línguas, pelos menos para uma grande parcela da população brasileira, a resposta seria negativa. Mesmo assim, acreditamos que essa vivência acolhedora na formação inicial pode ser a base de resiliência para que eles atuem em contextos mais desafiadores e para manterem essa paixão viva. Isso nos leva a pensar em um estudo futuro que possa acompanhar esses participantes após terem se formado para ver se e como a paixão por ensinar ainda se mantém.

Em terceiro lugar, os resultados deste estudo também confirmam o que é relatado na literatura sobre paixão pelo ensino (DAY, 2004; CARBENNEAU, 2008; MART, 2013) em relação às características de professores apaixonados: a paixão por ensinar desse grupo de professores está relacionada à interação com seus estudantes, a criação de ambientes que possam favorecer um ensino de qualidade e gerar emoções positivas, a fim de se sentirem motivados ainda mais pelo seu trabalho e também para saber lidar com as emoções negativas que poderão surgir no desenvolvimento de suas (futuras) práticas (DAY, 2004,2009).

Por fim, é importante destacar a contribuição da Narrativa Visual como um dos instrumentos de coleta de dados. Conforme apontado por Pitkänen-Huhta e Pietikäinen (2008), a NV possibilitou visualizar a paixão pelo ensino desses alunos ao vivenciarem a prática docente ainda no estágio inicial de sua formação profissional, especificamente no curso de LI onde estagiam, contexto retratado como importante à vivência do desejo de ensinar.

Este trabalho traz duas implicações para o ensino e aprendizagem de línguas e para a formação de professores. A primeira diz respeito à existência de professores em formação inicial que querem atuar como professores de inglês após se formarem, contrapondo resultados de outros estudos referentes a pouca atratividade na carreira docente (GIMENEZ, 2009; GATTI, 2010). Dado esse fato, tem-se a importância dos formadores de professores procurarem conhecer como se constitui o desejo em lecionar, 
a paixão pelo ensino, intenções, perspectivas e medos em relação à profissão docente de alunos-professores. Estes aspectos não devem ser ignorados pelos formadores de professores na busca de preparar os futuros professores de forma efetiva para suas práticas futuras frente à diversidade de contextos de ensino (DAY, 2009). A segunda implicação se refere à importância da prática docente na formação inicial, conforme sugere a literatura sobre formação de professores. Este estudo mostrou o relevante papel da prática para a identidade profissional desses professores. É importante também que os cursos de Letras promovam projetos de ensino, pesquisa e extensão, a fim de proporcionarem aos futuros docentes experiências de ensino que contribuam para o desenvolvimento de sua identidade docente ao conhecer mais sobre essa carreira, metodologias e estratégias de ensino que podem auxiliar em sua formação.

Trabalhos futuros poderiam investigar como professores de inglês em serviço se sentem (ou não) apaixonados pelo seu trabalho, em especial, aqueles que exercem seu trabalho em escolas regulares, uma vez que ensino nesse contexto é visto na literatura, por vezes, como fracassado, devido à desvalorização crescente profissional em termos financeiros e condições de trabalho e, mais recentemente, a culpabilização dos professores em geral. Acreditamos que esse tipo de estudo também pode identificar como as crenças desses professores em serviço em relação a sua profissão e ao contexto de ensino em que estão inseridos influenciam sua paixão para lecionar. Uma segunda sugestão de trabalho futuro diz respeito a estudos que relacionem a paixão, a motivação e a identidade de professores de inglês em formação continuada.

Esperamos que esta pesquisa possa, primeiramente, fornecer subsídios teóricos e práticos que contribuam à reflexão de professores em formação inicial e em serviço sobre a paixão pelo ensino, seus obstáculos e benefícios. Depois, esperamos que este estudo possa contribuir com as pesquisas sobre emoções e formação de professores de línguas na área da LA, na compreensão da paixão pelo ensino, instigando mais pesquisas nessa área, auxiliando professores em formação inicial e em serviço, bem como formadores de professores a perceberem que o ensino não é somente um trabalho intelectual e prático, mas também emocional (DAY, 2004). Desejamos que os professores possam também desfrutar de autonomia e liberdade de professarem essa paixão (se assim quiserem e desejarem) pelo ensino sem serem rotulados de alienados, ingênuos e/ou acríticos.

\section{REFERÊNCIAS}

ARAGÃO, R. Emoções e pesquisa narrativa: transformando experiências de aprendizagem. Revista Brasileira de Linguística Aplicada, Londrina, v. 8, n. 2, p. 295-320. 2008. 
ARCANJO, A. J. A. Emoções e motivações de professores em formação para o ensino de Língua Inglesa. 2019. 160 f. Dissertação (Mestrado) - Programa de Pós-graduação em Letras, Universidade Federal de Viçosa, Viçosa-MG, 2019a.

ARCANJO, S. C. A Relação entre motivação e emoções de uma professora de inglês em formação inicial. 2019. 149 f. Dissertação (Mestrado) - Programa de Pós-graduação em Letras, Universidade Federal de Viçosa, Viçosa-MG, 2019 b.

BARCELOS, A. M. F.; COELHO, H. S. H. Language Learning and Teaching: What's Love Got To Do With It?. In: MACINTYRE, P. D. et al. (Org.) Positive Psychology in SLA. Nova York: Multilingual Matters, 2016. p. 130-144.

BARCELOS, A.M.F. Unveiling the relationship between language learning beliefs, emotions, and identities. Studies in Second Language Learning and Teaching, Poznań, v. 5, p. 301-325, nov. 2015.

BATTISTELLA, T. R. Os efeitos das emoções no ensino-aprendizagem de inglês e na formação do futuro professor: uma análise com base no feedback corretivo oral. Revista Horizontes De Linguística Aplicada, Porto Alegre, v. 14, n. 2. 2015.

BENESCH, S. Emotions as agency: Feeling rules, emotion labor, and English language teachers' decision-making. System, vol. 79, p. 60-69. 2018.

BORGES, T. D.; LAGO, N. A. Para se aprender inglês, é preciso que o aluno tenha paixão pelo idioma: em que acredita um aluno iniciante do curso de Letras (inglês)?. Anais ABRALIC, p. 2845-2850, 2009.

BOSMA, H. A.; KUNNEN, E. S. Determinants and mechanisms in Ego identity development: A review and synthesis. Developmental Review, v. 21, n.1, p.39-66. 2001.

CANDIDO RIBEIRO, D. Estados afetivos de professoras de Língua Inglesa em formação inicial. 2012. 140 f. Dissertação (Mestrado) - Programa de Pós-graduação em Letras, Universidade Federal de Viçosa, Viçosa-MG, 2012.

CARBONNEAU, $N$. et al. The role of passion for teaching in intrapersonal and interpersonal outcomes. Journal of Educational Psychology, Québec, v.100, n. 4, p. 977987. 2008.

CARVALHO, A. M. A detailed look at public school in-service EFL teachers' selfesteem. 2020. 110 f. Dissertação (Mestrado) - Programa de Pós-graduação em Letras, Universidade Federal de Viçosa, Viçosa-MG, 2020. 
COELHO, H. S. Experiências, emoções e transformações na educação continuada. 2011. 176f. Tese (Doutorado em Estudos Linguísticos) - Universidade Federal de Minas Gerais (UFMG), Belo Horizonte-MG, 2011.

CRUZ, E.S. Professora sim, mas de inglês!: a paixão pela língua inglesa como condicionante para o magistério. Anais do I Simpósio de Linguística, Literatura e Ensino do Tocantins, p.124-134, 2013.

DAY, C. A passion for quality: teachers who make a difference. Tijdschrift voor Lerarenopleiders, Vlaanderen, v.30, n. 3, p.4-13, 2009.

DAY, C. A passion for teaching. London: Routledge Falmer, 2004.

DENZIN, N. K.; LINCOLN, Y. S. O planejamento da pesquisa qualitativa: teorias e abordagens. Curitiba: Artmed, 2006.

FLORES, M.A. Formação docente e identidade profissional: tensões e (des)continuidades. Educação, Porto Alegre, v. 38, n. 1, p. 138-146, jan-abr, 2015.

FREIRE, P. Pedagogia da autonomia: saberes necessários à prática educativa. São Paulo: Paz e Terra, 1996.

GATTI, B. A. Formação de professores no Brasil. Educ. Soc., Campinas, v. 31, n. 113, p. 1355-1379, out.-dez, 2010.

GIMENEZ, T. Por uma Tipologia de Projetos de Formação Continuada de Professores de Inglês. In: TELLES, J. (Org.). Formação Inicial e Continuada de Professores de Línguas: Dimensões e Ações na Pesquisa e na Prática. Campinas, SP: Pontes, 2009. p. 137-151.

GODOY, P. F. G. Crenças e emoções de uma professora formadora de Língua Inglesa e de seus alunos: Um estudo de caso. 2020. 225 f. Dissertação (Mestrado) - Programa de Pós-graduação em Letras, Universidade Federal de Viçosa, Viçosa-MG, 2020.

GILES, C.; HARGREAVES, A. The Sustainability of Innovative Schools as Learning Organizations and Professional Learning Communities During Standardized Reform. Educational Administration Quarterly, v. 42, n. 1, p. 124-156, fev. 2006.

HARDEN, R. M.; LAIDLAW, J.M. Essential Skills for a Medical Teacher: An Introduction to Teaching and Learning in Medicine. Rio de Janeiro: Elsevier, 2012. 
HARGREAVES, A. et al. Change frames: Supporting secondary teachers in interpreting and integrating secondary school reform (Unpublished final report). Toronto: Ontario Institute For Studies In Education (Oise), University Of Toronto, And Peel University Partnership., 2000.

HOLLIDAY, A. Doing and writing qualitative research. London: Sage Publications, 2002.

IZARD, C. E. The psychology of emotions. New York: Plenum, 1991.

KALAJA, P.; ALANEN, R.; DUFVA, H. Self-portraits of EFL learners: Finnish students draw and tell. In: KALAJA, P.; MENEZES, V.; BARCELOS, A. M. F., Narratives of learning and teaching EFL. Basingstoke: Palgrave Macmillan, p. 186-98, 2008.

KING, J. Teacher Emotions and Emotional Labour of Second Language Teaching. In: MERCER S.; KOSTOULAS, A. Language Teacher Psychology. Multilingual Matters, 2018. Disponível em: https://doi.org/10.21832/9781783099467 Acesso em: 20 set. 2020.

LEFFA, V. J. Aspectos políticos da formação do professor de línguas estrangeiras. In: LEFFA, Vilson J. (Org.). O professor de línguas estrangeiras: construindo a profissão. Pelotas: Editora Pelotas, 2001. p. 333-355.

LIMA, M. D. Não quero mais ser professor! Análise semiótica de depoimentos de docentes que desistiram da profissão. 2016. 191f. Dissertação (Mestrado). Curso de Mestrado em Ensino de Língua e Literatura, Departamento de Letras, Universidade Federal de Tocantins, Araguaína-TO, 2016.

MART. C. T. A Passionate Teacher: Teacher Commitment and Dedication to Student Learning. International Journal of Academic Research in Progressive Education and Development, Usa River, v. 2, n.1, p. 226-348, jan. 2013.

MESQUITA, B.; MARKUS, H. R. Culture and Emotion: Models of Agency as Sources of Cultural Variation in Emotion. In A. S. R. Manstead, N. Frijda, \& A. Fischer (Eds.), Studies in emotion and social interaction. Feelings and emotions: The Amsterdam symposium. University Press, 2004. Disponível em: https://www.researchgate.net/ publication/232599731_Culture_and_emotion_Models_of_agency_as_sources_of_ cultural_variation_in_emotion Acesso em: 20 set. 2020.

MOREIRA, J. B. O desejo de ser professor de inglês. Jornada de Estudos Linguísticos e Literários: JELL/UFV, p. 150-166, 2017. Disponível em: https://www.brazilianstudies. com/ojs/index.php/jellufv/article/view/272\%3E.\%20Acesso\%20em:\%2019\%20jul.\%20 2017 Acesso em: 19 jul. 2017. 
MOREIRA, J. B. O ensino de inglês na escola pública: O que os aluno desejam?. 2015. 58f. Monografia (Graduação) - Curso de Graduação em Letras, Universidade Federal de Viçosa, Viçosa-MG, 2015.

OLIVEIRA, B. M. Crenças, motivações e identidades de alunos de língua inglesa de uma escola particular. 2016. 137f. Dissertação (Mestrado). Programa de Pós- graduação em Letras, Universidade Federal de Viçosa, Viçosa-MG. 2016.

OLIVEIRA, L. A. Métodos de ensino de inglês: teorias, práticas e ideologias. São Paulo: Parábola, 2012.

PADULA, B. C. Emoções de uma Professora de Inglês de escola regular: o papel do coaching. 2016. 152 f. Dissertação (Mestrado em Estudos Linguísticos) - Universidade Federal de Viçosa, Viçosa, MG, 2016.

PAIVA, V. L. M. O. A identidade do professor de inglês. APLIEMGE: Ensino e Pesquisa, Uberlândia, n.1, p. 9-17, 1997.

PALMER. M. M. Beliefs, identities and social class of English Language learners:A comparative study between the United State and Brazil. 2018. 194 f. Dissertação (Mestrado) - Programa de Pós-graduação em Letras, Universidade Federal de Viçosa, Viçosa-MG, 2018.

PITKANEN-HUHTA, A; PIETIKAINEN, S. Visual methods in researching language practices and language learning: - looking at, seeing and designing language, Encyclopedia of Language and Education, 2008.

PITKANEN-HUHTA, A.; PIETIKAINEN, S. Visual methods in researching language practices and language learning looking at, seeing and designing language. In: KING, K. A., LAI, Y. \& MAY, S. (Eds.), Research Methods in Language and Education. Dordrecht: Springer, 2014.

REZENDE, T. C. Autoestudo sobre as emoções de uma professora de inglês em uma escola pública. 2014. 120f. Dissertação (Mestrado em Letras) - Universidade Federal de Viçosa, Viçosa-MG, 2014.

RODRIGUES, N. N. Relationships Between Pre-Service Teachers'Emotions And Beliefs About Learning And Teaching English. 2015. 168 f. Dissertação (Mestrado em Estudos Linguísticos) - Universidade Federal de Viçosa, Viçosa-MG, 2015.

SILVA, J. B. M. Vozes apaixonadas pelo ensino de inglês: A construção da identidade dos professores em formação inicial. 2018. 117 f. Dissertação (Mestrado) - Programa de Pósgraduação em Letras, Universidade Federal de Viçosa, Viçosa-MG, 2018. 
SO, D. Emotion processes in second language acquisition. In: BARCELOS A.M.F. Unveiling the relationship between language learning beliefs, emotions, and identities. Studies in Second Language Learning and Teaching, 2015. p. 301-325.

SOLOMON, R. On the passivity of the passions. In: MANSTED, A. S. R.; FRIJDA, N.; FISCHER, A. (Eds.), Feelings and emotions: The Amsterdam Symposium. Cambridge: Cambridge University Press, p. 11-29, 2004.

SOUZA, J. A. O papel da reflexão na construção da identidade profissional do professor de língua inglesa. In: CALVO, L. C. S.; EL KADRI, M. S.; ORTENZI, D. B.G; SILVA, E K. A. (Orgs.) Reflexões sobre ensino de línguas e formação de professores no Brasil. Campinas, SP: Pontes, 2013. p. 83-119.

TARDIF, M. Saberes docentes e formação profissional. 16 ed. Petrópolis, Rio de Janeiro: Vozes, 2014.

ZEMBYLAS, M. Structures of feeling in curriculum and teaching: theorizing the emotion rules. Educational theory, Urbana, v. 52, n.2, p. 187-298. 2002a.

ZEMBYLAS, M. Constructing Genealogies of teachers' emotions in Science teaching. Journal of research in Science Teaching. v. 39, n.1, p. 79-103. 2002 b.

ZEMBYLAS, M. Caring for teacher emotion: reflection on teacher self-development. Studies in Philosophy and Education, Netherland, n. 22, p. 103-125. 2003.

ZEMBYLAS, M. The emotional characteristics of teaching. Teaching and Teacher Education, v. 20, n.2, p. 185-201, 2004.

ZEMBYLAS, M. Beyond teacher cognition and teacher beliefs: the value of the ethnography of emotions in teaching. International Journal of Qualitative studies in Education, Londres, v. 18, n. 4, p. 465-487, jul-ago. 2005.

Recebido em: 11 out. 2020. Aceito em: 27 jan. 2021. 